\title{
YIELD COMPONENTS IN MUNG BEAN [Vigna radiata (L.) Wilczek]
}

\author{
Huseyin CANCI", Cengiz TOKER \\ Akdeniz University, Faculty of Agriculture, Department of Field Crops, Turkey. \\ *Corresponding author: huseyincanci@akdeniz.edu.tr
}

Received:29.01.2014

\begin{abstract}
This study was conducted to evaluate the yield components in mung bean [Vigna radiata (L.)Wilczek] using the correlation, path and factor analyses. It was found that there was considerable variation for the characters studied. Factor 1 composed of 100-grain weight, podlength, pod width, branches per plant and pods per plant. The grain weight was stronglycorrelated with pod length and pod width. Pods per plant were significantly and positivelyassociated with branches per plant. Factor 2 consisted of biological, straw and grainyields. The seed yield was highly associated with biological and straw yields. Factor 3 comprised of seed per pod, pods and flowers per peduncle. The fourth factor was onlythe days to flowering. The last factor was plant height. The total factors had $74 \%$ ofthe total variance induced by the characters. It was firstly concludedthat the factor analysis together with path and correlationcoefficients could successfully be used for determining characters usable for selection in themung bean breeding programs.
\end{abstract}

Key words: Correlation analysis, Factor analysis, Mung bean, Path analysis, Selection criteria,Vigna radiata

\section{INTRODUCTION}

Genetic relationships between yield and yield related characters are prerequisite in selecting desirabletypes for the target environment. Some of the yield components are highly interrelated. On the other hand, grain yield is governed by many genetic aswell as environmental factors that are interdependent. Heritability for grain yield is lowin mung bean (Tickoo and Jain, 1988); as well as in chickpea (Toker, 1998; 2004). Path coefficientanalysis ishelpful to determine the direct contribution of yield components and their indirect contributionsover other traits on grain yield (Dewey and Lu, 1959). Path analysis has been widely used to determine direct andindirect selection criteria in food legumes (Duarte and Adams, 1972; Bahl et al., 1976; Islam and Shaikh, 1978; Toker and Cagirgan, 2003).

Cattel (1965) explained that the factor analysis has decreased a large number of correlated variables to a small number of main factors. Ithas been successfully utilized in wheat (Lee and Kaltsikes, 1973), in switch grass(Godshalk and Timothy, 1988) and in barley(Cagirgan and Yildirim, 1990) as well as in chickpea (Toker, 2004; Toker and Cagirgan, 2004). Until today, any selection criteria have not been proposed to determine characteristicsrelated to grain yield in mung bean. The objective of this study was to determine the yield component of mung bean by using the path and factor analysis.

\section{MATERIALS AND METHODS}

A total of nineteen mung bean genotypes, 17 from Nuclear Institute for Agriculture andBiology (NIAB); one genotype from market of Faisalabad, Pakistan; and one genotype fromGazipasa, Antalya, Turkey were grown in the lowland conditions (approximately $30^{\circ} 44^{\prime}$ E, $36^{\circ} 52^{\prime}$ $\mathrm{N}, 51 \mathrm{~m}$ from sea level) of the west Mediterranean region of Turkey during 1999-2000 and2000-2001 growing seasons. Grains of genotypes were sown on May 18, 2000 and on May 7,2001 in a Randomized Complete Block Design with 3 replications and oneexperimental plot consisted of two rows of $2 \mathrm{~m}$ length $30 \mathrm{~cm}$ apart and 10 $\mathrm{cm}$ in the row spacing. Fertilization was applied at a rate of $20 \mathrm{~kg}$ nitrogen and $50 \mathrm{~kg}$ phosphorus perhectare prior to sowing. The experimental area was irrigated with sprinkler system with 10 daysintervals. Weeds were controlled by hand without using any chemicals. Some important phenologic, morphologic and agronomic characters were recorded.These characters were described in Descriptors for Vigna mungo and $V$. radiata (IBPGR,1985). Phenological descriptors: Days to flowering (DF) was recorded in days as number ofdays after sowing when $50 \%$ plants in the plot set the first flower. Morphological descriptors:Plant height (PH) was 
recorded in $\mathrm{cm}$ as average height from ground to top of two plants atmaximum growth. Branches per plant (BP) were average number of stems from two plants atflowering. Pods per plant (PP) were average number of pods from two plants at podding.Flowers per peduncle (FN) were recorded in number as average of flowers from two plants. Podsper peduncle (PN) were average number of pods from two plants. Pod length (PL) was recordedin $\mathrm{cm}$ as average length of pods of two plants at maximum growth. Pod width (PW) wasrecorded in $\mathrm{cm}$ as width of pod of two plants at maximum growth. Grains per pod (GP) wererecorded as grains of pod in two plants at maximum growth. Agronomicaldescriptors: Grain yield (GY) was recorded in $\mathrm{g}$ and then converted to $\mathrm{kg}$ ha-1 basis as afterthreshing seed weight each genotype. Biological yield (BY) was recorded in $\mathrm{g}$ after harvesting astotal dry weight each genotype. Straw yield (SY) was calculated following to the formula:[(Biological yield) (Grain yield)] as g. 100-Seed weight (SW) was recorded in $\mathrm{g}$ as average oftwo times randomly 100 grains selected.Path and factor analyses were performed according to Dewey and Lu (1959) and Cattel(1965), respectively. Analyses were performed by using MINITAB statistical package programs (MINITAB, 2000).

\section{RESULTS AND DISCUSSION}

Considerable variations were found for all the 13 characteristics studied, even though limitedgenotypes have been evaluated (Table 1).It could be seen in Table 2 that grain yield was significantly andpositively correlated the biological yield $(r=0.688)$, pods per plant $(r=0.682)$, pods perpeduncle $(\mathrm{r}=0.654)$, plant height $(\mathrm{r}=0.602)$, days to flowering $(\mathrm{r}=0.593)$, branches per plant $(\mathrm{r}=$ $0.585)$, straw yield $(r=581)$, grains per pod $(r=0.574)$, flowers per peduncle $(\mathrm{r}=0.556)$ andpods width $(\mathrm{r}=$ 0.510). The biological yield was strongly and positively associated with strawyield $(\mathrm{r}=0.989)$, plant height $(\mathrm{r}=$ $0.834)$, days to flowering $(\mathrm{r}=0.690)$ and pods per plant $(\mathrm{r}$ $=0.479$ ). Grain weight $100^{-1}$ was highly and positively related with pod length $(r=0.905)$, podwidth $(r=0.880)$, plant height $(r=0.831)$, pods per peduncle $(r=0.692)$ and days to flowering $(r=0.625)$. Biological yield $(6.034)$ had the highest direct and positive effect, while 100-grain weight(0.011) was the lowest contribution to grain yield (Table 3).Biological yield was followed by straw yield with negative direct effect $(-5.848)$ and days toflowering with positive direct effect (0.797). The indirect effect of biological yield via straw yield (-5.784) was negative and high on grain yield (Table 3).

Table 1. The mean, standard error, minimum and maximum values of 13 characters in mung bean

\begin{tabular}{|c|c|c|c|}
\hline Characters & Mean \pm SE & Minimum & Maximum \\
\hline Days to Flowering (days) & $58.2 \pm 0.94$ & 20.0 & 76.0 \\
\hline Plant height $(\mathrm{cm})$ & $48.1 \pm 1.44$ & 19.5 & 91.0 \\
\hline Branches per plant & \pm 0.07 & 2.0 & 6.0 \\
\hline Pods per plant & \pm 1.13 & 8.0 & 62.5 \\
\hline Flowers per peduncle & \pm 0.07 & 3.5 & 7.0 \\
\hline Pods per peduncle & \pm 0.03 & 2.0 & 4.0 \\
\hline Pod length $(\mathrm{cm})$ & \pm 0.17 & 5.6 & 20.0 \\
\hline Pod width (cm) & \pm 0.01 & 0.3 & 0.6 \\
\hline Grains per pod & \pm 0.15 & 5.0 & 13.0 \\
\hline Biological yield (g plot-1) & \pm 44.10 & 41.0 & 2520.0 \\
\hline Straw yield (g plot-1) & \pm 39.10 & 22.0 & 2150.0 \\
\hline Grain yield (kg ha-1) & 1209.6 & 33.3 & 3916.6 \\
\hline 100 -grain weight $(\mathrm{g})$ & \pm 0.14 & 3.1 & 8.6 \\
\hline
\end{tabular}

Table 2. Correlations among 13 characters in mung bean $(\mathrm{df}=17)$

\begin{tabular}{|c|c|c|c|c|c|c|c|c|c|c|c|c|}
\hline Characters & $\mathrm{PH}$ & BP & PP & FN & PN & PL & PW & GP & BY & SY & GY & SW \\
\hline $\mathrm{DF}$ & $0.805 * *$ & $0.525^{*}$ & 0.354 & $0.558^{*}$ & $0.831^{* *}$ & $0.714 * *$ & $0.779 * *$ & $0.693^{* *}$ & $0.690 * *$ & $0.675^{* *}$ & $0.593^{* *}$ & $0.625^{* *}$ \\
\hline PH & & $0.525 *$ & $0.587 * *$ & $0.558 *$ & $0.587 * *$ & 0.384 & $0.453^{*}$ & $0.555^{*}$ & $0.834 * *$ & $0.831 * *$ & $0.602 * *$ & 0.222 \\
\hline BP & & & $0.755^{* *}$ & $0.840 * *$ & $0.737 * *$ & $0.462 *$ & $0.466^{*}$ & $0.731^{* *}$ & 0.427 & 0.371 & $0.585^{* *}$ & 0.275 \\
\hline PP & & & & $0.536^{*}$ & $0.532 *$ & 0.290 & 0.345 & $0.482 *$ & $0.479 *$ & 0.397 & $0.682 * *$ & 0.140 \\
\hline FN & & & & & $0.825^{* *}$ & $0.555^{*}$ & $0.571 * *$ & $0.800^{* *}$ & 0.297 & 0.238 & $0.556^{*}$ & 0.357 \\
\hline PN & & & & & & $0.811 * *$ & $0.865^{* *}$ & $0.820^{* *}$ & 0.409 & 0.343 & $0.654^{* *}$ & $0.692 * *$ \\
\hline PL & & & & & & & $0.918^{* *}$ & $0.723^{* *}$ & 0.194 & 0.138 & 0.433 & $0.905^{* *}$ \\
\hline PW & & & & & & & & $0.740^{* *}$ & 0.312 & 0.258 & $0.510^{*}$ & $0.880 * *$ \\
\hline GP & & & & & & & & & 0.257 & 0.185 & $0.574 * *$ & $0.596 * *$ \\
\hline BY & & & & & & & & & & $0.989 * *$ & $0.688 * *$ & 0.090 \\
\hline SY & & & & & & & & & & & $0.581 * *$ & 0.057 \\
\hline GY & & & & & & & & & & & & 0.268 \\
\hline
\end{tabular}
Pods per peduncle, $\mathrm{PL}=$ Pod length, $\mathrm{PW}=$ Pod width, $\mathrm{GP}=\mathrm{Grains}$ per pod, $\mathrm{BY}=$ Biological yield, $\mathrm{SY}=\mathrm{Straw}$ yield, $\mathrm{GY}=$
Grain yield, $\mathrm{SW}=100$-seed weight. Degrees of freedom is df. $\mathrm{P}<0.456$ and 0.575 statistically significant at 0.05 and 0.01 probability levels, respectively. 
Table 3. The direct and indirect contribution of characters to grain yield in mung bean

\begin{tabular}{lrrrrrrrrrrrr}
\hline & GW & \multicolumn{1}{c}{ PL } & \multicolumn{1}{c}{ PW } & \multicolumn{1}{c}{ BP } & \multicolumn{1}{c}{ PP } & \multicolumn{1}{c}{ BY } & \multicolumn{1}{c}{ SY } & \multicolumn{1}{c}{ GP } & \multicolumn{1}{c}{ PP } & \multicolumn{1}{c}{ FP } & \multicolumn{1}{c}{ DF } & PH \\
\hline GW & $\mathbf{0 . 0 1 1}$ & 0.010 & 0.010 & 0.003 & 0.002 & 0.001 & 0.001 & 0.007 & 0.008 & 0.004 & 0.007 & 0.003 \\
PL & -0.231 & $\mathbf{- 0 . 2 5 9}$ & -0.234 & -0.118 & -0.074 & -0.049 & -0.035 & -0.184 & -0.207 & -0.141 & -0.182 & -0.098 \\
PW & -0.256 & -0.267 & $\mathbf{- 0 . 2 9 1}$ & -0.135 & -0.100 & -0.091 & -0.075 & -0.215 & -0.251 & -0.166 & -0.227 & -0.132 \\
BP & -0.080 & -0.133 & -0.135 & $\mathbf{- 0 . 2 8 9}$ & -0.218 & -0123 & -0.107 & -0.211 & -0.212 & -0.243 & -0.201 & -0.152 \\
PP & 0.010 & 0.020 & 0.024 & 0.052 & $\mathbf{0 . 0 6 8}$ & 0.033 & 0.027 & 0.033 & 0.036 & 0.037 & 0.030 & 0.024 \\
BY & 0.543 & 1.170 & 1.884 & 2.575 & 2.892 & $\mathbf{6 . 0 3 4}$ & 5.968 & 1.552 & 2.465 & 1.791 & 4.161 & 5.032 \\
SY & -0.332 & -0.806 & -1.508 & -2.168 & -2.324 & -5.784 & $\mathbf{- 5 . 8 4 8}$ & -1.082 & -2.006 & -1.392 & -3.950 & -4.859 \\
GP & -0.017 & -0.021 & -0.022 & -0.021 & -0.014 & -0.008 & -0.005 & $\mathbf{- 0 . 0 2 9}$ & -0.024 & -0.023 & -0.020 & -0.016 \\
PP & 0.119 & 0.140 & 0.149 & 0.127 & 0.092 & 0.070 & 0.059 & 0.141 & $\mathbf{0 . 1 7 2}$ & 0.142 & 0.143 & 0.101 \\
FP & -0.016 & -0.025 & -0.027 & -0.038 & -0.024 & -0.014 & -0.011 & -0.036 & -0.038 & $-\mathbf{- 0 . 0 4 5}$ & -0.031 & -0.025 \\
DF & 0.498 & 0.569 & 0.621 & 0.555 & 0.355 & 0.550 & 0.539 & 0.553 & 0.663 & 0.547 & $\mathbf{0 . 7 9 7}$ & 0.642 \\
PH & 0.018 & 0.032 & 0.037 & 0.043 & 0.029 & 0.069 & 0.068 & 0.046 & 0.048 & 0.046 & 0.066 & $\mathbf{0 . 0 8 2}$ \\
\hline
\end{tabular}

$\mathrm{DF}=$ Days to flowering, $\mathrm{PH}=$ Plant height, $\mathrm{BP}=$ Branches per plant, $\mathrm{PP}=$ Pods per plant, $\mathrm{FN}=$ Flowers per peduncle, $\mathrm{PN}=\mathrm{Pods}$ per peduncle, $\mathrm{PL}=$ Pod length, $\mathrm{PW}=$ Pod width, GP = Grains per pod, BY = Biological yield, $\mathrm{SY}=$ Straw yield, GY $=\mathrm{Grain}$ yield, $\mathrm{SW}=100$-seed weight.

It could be seen in Table 4 that 5 factors explained $74 \%$ of the total variance of the characters. Factor 1, 2, 3, 4and 5 explained $0.26 \%, 0.18 \%, 0.15 \%, 0.08 \%$ and $0.07 \%$ of total variance expressed. Factor 1comprised of 100- grain weight $(-0.729)$, pod length $(-0.655)$, pod width $(-0.631)$, branches perplant $(0.591)$ and pods per plant $(0.486)$ whereas factor 2 composed of biological yield (0.675), straw yield (0.613) andgrain yield (0.612) with positive loadings. Factor 3 consisted of grains per pod (0.626), pods per peduncle (0.505) and flowers per peduncle (0.471), while factor 4 encompassed days to flowering with negative loading $(-0.697)$. The last factorconsisted of only plant height with negative loading $(-0.598)$.

Table 4. Factor loadings and communalities of 13 characters on five principal factors in mung bean

\begin{tabular}{|c|c|c|c|c|c|c|}
\hline \multirow[t]{2}{*}{ Characters } & \multicolumn{5}{|c|}{ Factors } & \multirow[t]{2}{*}{ Communality } \\
\hline & 1 & 2 & 3 & 4 & 5 & \\
\hline 100-grain weight & -0.729 & 0.479 & 0.130 & -0.155 & -0.029 & 0.80 \\
\hline Pod length & -0.655 & 0.472 & 0.236 & -0.047 & -0.145 & 0.73 \\
\hline Pod width & -0.631 & 0.579 & 0.147 & -0.113 & -0.009 & 0.76 \\
\hline Branches per plant & 0.591 & -0.105 & 0.342 & -0.525 & -0.072 & 0.75 \\
\hline Pods per plant & 0.486 & 0.212 & 0.466 & -0.050 & -0.224 & 0.55 \\
\hline Biological yield & 0.623 & 0.675 & -0.228 & 0.052 & 0.231 & 0.95 \\
\hline Straw yield & 0.593 & 0.613 & -0.327 & 0.003 & 0.280 & 0.91 \\
\hline Grain yield & 0.458 & 0.612 & 0.310 & 0.265 & -0.134 & 0.76 \\
\hline Grains per pod & 0.010 & -0.050 & 0.626 & 0.124 & -0.327 & 0.51 \\
\hline Pods per peduncle & 0.078 & 0.260 & 0.505 & -0.400 & 0.371 & 0.62 \\
\hline Flowers per peduncle & 0.450 & -0.373 & 0.471 & -0.204 & 0.211 & 0.65 \\
\hline Days to Flowering & -0.038 & 0.066 & -0.575 & -0.697 & -0.273 & 0.89 \\
\hline Plant height & 0.489 & 0.223 & -0.193 & -0.006 & -0.598 & 0.68 \\
\hline Variance & 3.34 & 2.31 & 1.92 & 1.10 & 0.95 & 9.62 \\
\hline$\%$ Variance & 0.26 & 0.18 & 0.15 & 0.08 & 0.07 & 0.74 \\
\hline
\end{tabular}

Bold and italic numbers are the main factors.

Variation is the first requirement for selection in plant breeding. Bosand Caligari (1995) pointed out that the more genetic variation in characters is the more genetic gain.Ahmed et al. (1981) reported that pods per plant were the most important selectioncriteria to increase potential yield in mung bean. In black gram [Vigna mungo (L.)Hepper], it was shown that plant yield was significantly correlated with grains per pod, pods perplant, main branches per plant and plant height (Majid et al., 1982). Shamsuzzaman et al. (1983)studied for genetic, phenotypic and environmental correlations in mung bean. They found thatplant height was strongly associated with main branches per plant and pods per plant. Similarresults were obtained by Remanandan et al. (1988) in pigeonpea.Our results are in agreement with findings of Karadavut (2009). Biological yield could be accepted as the most valuable characteristicamong the traits.Biological yield had the highest direct effect on grain yield (Table 3)and biological yield could be increasedvia straw yield, branches per plant andpods per peduncle. The biological yield in chickpeawas found to be the most important selection criteria for the contributing grain yield due to the highest and the positive direct effect (Canci and Toker, 2009). The more branches per plant resulted in the more 
pods per plant. To utilize pods per peduncle characteristic, genotypes with high numbering flowers per peduncle should be selected. Besides, the days to flowering and plant height should also beevaluated. In a similarway, selection criteria to be usedin chickpea were evaluated (Toker andCagirgan, 2004). Toker (2004) stressed that biological yield should be evaluated in the selectionto increase the grain yield in chickpea breeding programs.

In conclusion, biological or straw yield could beused as selection criteria in mung bean. Besides, selection of genotypes with large seed, high podwidth and length could also be considered.

\section{ACKNOWLEDGEMENTS}

This study was supported by Akdeniz University The Scientific Research Projects Coordination Unit.A special thanks would like to Dr. A.M. Haq from National Institute ofAgriculture and Biology (NIAB), Faisalabad, Pakistan and Yasar Ozyigit (Asst. Prof. Dr.) fromKorkuteli Vocational School, Horticultural Program, Akdeniz University, Antalya, Turkey forkindly providing plant materials.

\section{LITERATURE CITED}

Ahmed, Z.U., M.A.Q. Shaikh, M.A. Majid and S. Begum, 1981. Correlation studies in agronomiccharacters of mung bean (Vigna radiata). Bangladesh Journal of Agricultural Science 8:3-36.

Bahl, P.N., R.B. Mehra and D.B. Raju, 1976. Path analysis and its implications for chickpea breeding. Z. Pflanzenzüchtung 77: 67-71.

Bos, I., and P. Caligari, 1995. Selection Methods in Plant Breeding. Published by Chapman andHall, 2-6 Boundary Row, London, SE1 8HN, UK.

Cagirgan, M.I. and M.B. Yildirim, 1990. An application of factor analysis to data from control andmacro mutant populations of 'Quantum' barley. J. Fac. of Agric. of Akdeniz University4: 125-138.

Canci, H. and C. Toker, 2009. Evaluation of Yield Criteria for Drought and Heat Resistance in Chickpea (Cicer arietinum L.). J. Agronomy \& Crop Science 195: 47-54.

Cattel, R.B., 1965. Factor analysis: An introduction to essentials. I. The propose and underlyingmodels. Biometrics 21: 190215.

Dewey, D.L. and K.H. Lu, 1959. A correlation and pathcoefficient analysis of components ofcrested wheatgrass seed production. Agron. J. 51: 515-518.
Duarte, R.A. and M.W. Adams, 1972. A path coefficient analysis of some yield componentsinterrelations in field beans (Phaseolus vulgaris L.). Crop. Sci. 12: 579-582.

Godshalk, E.B. and D.H. Timothy, 1988. Factor and principal component analyses as alternativeto index selection. Theor. Appl. Genet. 76: 352-360.

IBPGR, 1985. Descriptors for Vigna mungo and V. radiata (Revised). International Board forPlant Genetic Resources, Rome, Italy.

Islam, M.Z. and M.A.Q. Shaikh, 1978. Correlation and pathcoefficient analysis of yield and yieldcomponents in lentil. Bangladesh Journal of Agricultural Science 5: 67-72.

Karadavut, U. 2009. Path analysis for yield and yield components in Lentil (Lens culinaris Medik.). Turkish J. of Field Crops, 14: 97-104.

Lee, J. and P.J. Kaltsikes, 1973. Multivariate statistical analysis of grain yield and agronomic characters in durum wheat. Theor. Appl. Genet. 43: 226-231.

Majid, M.A, S. Khanum, M.A.Q. Saikh and A.D. Bhuiya, 1982. Genetic variability and correlationstudies in black gram. Bangladesh Journal of Agriculture 7: 98-102.

MINITAB 2000. Minitab Statistical Software vers. 13.1

Remanandan, P., D.V.S.S.R. Sastry and M.H. Mengesha, 1988. ICRISAT Pigeonpea GermplasmCatalog: Evaluation and Analysis. Patencheru, A.P. 502 324, India.

Shamsuzzaman, K.M., M.R.H. Khan and M.A.Q. Saikh, 1983. Genetic variability and charactersassociation in mung bean [Vigna radiata (L.) Wilczek]. Bangladesh Journal ofAgricultural Res. 8: 1-5.

Tickoo, J.L. and H.K. Jain, 1988. Mungbean. In: B. Baldev, S. Ramanujam and H.K. Jain, (Eds.), Pulse Crops (Grain Legumes, Oxford and IBH Publishing Co. Pvt. Ltd. New Delhi, India, pp. 161-188.

Toker, C., 1998. Estimate of heritabilities and genotype by environment interactions for 100- grain weight, days to flowering and plant height in kabuli chickpeas (Cicer arietinum L.). Turk. J. Field Crops 3, 16-20.

Toker, C. and M.I. Cagirgan, 2003. Selection criteria in chickpea (Cicer arietinum). Acta Agric.Scan. Section B, Soil and Plant Science 53: 42-45.

Toker, C., 2004. Evaluation of selection criteria using phenotypic and factor analysis inchickpea. Acta Agric. Scan. Section B, Soil and Plant Science 54:45-48.10

Toker, C. and M.I. Cagirgan, 2004. The use of phenotypic correlations and factor analysis indetermining characters for grain yield selection in chickpea (Cicer arietinum L.).Hereditas 140: 226-228. 